\title{
ENHANCING STUDENTS' ORAL COMMUNICATION BY USING COMMUNICATIVE LANGUAGE TEACHING (CLT)
}

\author{
${ }^{1}$ Ahmad Wael, ${ }^{2}$ Dian Saputra, 3Eka Setyawati \\ ${ }^{1}$ Fakultas Keguruan dan Ilmu Pendidikan, Universitas Muhammadiyah Sorong \\ ${ }^{2}$ Fakultas Keguruan dan Ilmu Pendidikan, Universitas Muhammadiyah Sorong \\ ${ }^{3}$ Fakultas Keguruan dan Ilmu Pendidikan, Universitas Muhammadiyah Sorong
}

Email: ahmadwae1818@gmail.com,dian.ums14@gmail.com, ekasetiawati935@ gmail.com

\begin{abstract}
This article aims at providing students' oral communication in speaking class. There were two specific purposes to gain the data namely to find out the effects of Communicative Language Teaching (CLT) in teaching oral communication especially in speaking ability and to disclose the responses of students in the learning process by using Communicative Language Teaching (CLT). In order to obtain the comprehensive data, the writers used performance test and questionnaire with 32 respondents on speaking class. This research was applied in quantitative method. The writers used the design of interact group comparison. The result showed that there was a significant effect

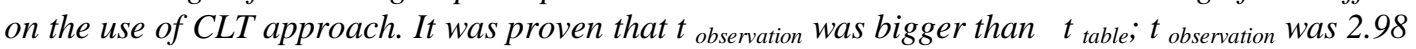
while $t_{\text {table }}$ was 2.021 (2.98> 2.021). Most of the students agreed if CLT was applied in teachinglearning activites, especially in speaking class because it could help them in improving their ability in oral communication. The results of their opinion towards the application of CLT were expressed by chosing option 4 (agree) and 5 (strongly agree) in every indicator. For indicator 1 and 10, students tent to choose option 5 (strongly agree) with the percentage of 56.3 and the mean of 2.8. In indicator 2 and 4, the students tent to choose option 5 with the percentage of 59.4 and the mean of 3.0. In indicator 3 and 7, the students tent to choose option 4 (agree) with the percentage of 62.5, and mean score of 2.5. For indicator 5 and 6, the students chose option 5 with the percentage of 50.0 and mean score of 2.5. For indicator 8 and 9, most of the students tent to choose option 5 (strongly agree). The percentage and mean score were different. In indicator 8 , the percentage was 56.3 with the mean score of 2.3 whereas in indicator 9, the percentage was 68.8 which the mean score of 2.8 more of the respondents were strongly agree with the application of CLT approach in speaking class. It made the students interestend in following speaking class and the students have confidence to speak with other friend or lecturer inside or outside the classroom.
\end{abstract}

\section{Keywords: Communicative Language Teaching, Oral Communication}

\section{INTRODUCTION}

Oral communication or speaking is one of the skills that must be owned by language learners. In learning to speak, students still found the difficulties to overcome their ability in speaking. By speaking, learners can communicate with others to achieve certain goals or to express their opinions, intentions, hopes and viewpoints (Amaliyah, R., Akib, M., \& Hartanti, R., 2018). It needs great attention to learn second language like English, as we know that English has a complicated rule such as structure and pronunciation which is far different with first Language of ESL learner (Akib. R., 20018). This condition made the students is lack of motivation to learn speaking. However, students in university level sometimes lack of exposure and practice in English. Learning is commonly defined as a process that brings together cognitive, emotional, and environmental influences and experiences for acquiring, enhancing, or making changes in one's knowledge, skills, 
values, and world views (Illeris, 2000; Ormorod, 1995). Learning as a process focuses on what happens when the learning takes place.

In addition, to dig the students' motivation to learn speaking as oral communication, the writer used the approach of Communicative Language Teaching (CLT) or Communicative Approach on teaching speaking. This approach is used to teach a second and foreign language that emphasizes on the interaction as both the means and the ultimate goal of learning of a language. It is also referred to as "communicative approach to the teaching of foreign language" or simply the "communicative approach". Effective communication is sought in CLT (Richard and Rodgeis, 1986: 67).

Teaching speaking is not an easy job. There are many problems in teaching speaking. First, it relates to the condition of the students who are lack of vocabulary that will make them unable to say words during speaking class. With a limited vocabulary anyone will also has a limited understanding in terms of speaking (Saputra. D., 2018). Second, most of students do not have confidence to use English in speaking class. Sometimes the students feel not confident to speak. Third, the students often speak their mother tongue. Beside that, it is caused by the learning process which is not effective because the approach of giving exposure and practice are low. The teachers or lecturers only give the material and explain it, but students are not forced by the teacher or lecturer to enhance their oral communication. The approach is not effective because the students are bored and need many times to be able to master English speaking especially in oral communication or speaking (Harmer, 1994).

Laddo (1961: 240) states that " Speaking ability is described as the ability to express oneself in life situation or the ability to report an act or situation in precise words, or the ability to converse or to express of ideas fluently. However, Clark and Clark (1977: 272) also state that: "Speaking is one of the two basic activities besides listening in communication using a language. In speaking, people put ideas into words, talking about their perceptions, feelings and intentions. They want other people to comprehend. They ask listener or receivers to get some information".

Considering the real condition above, the writer would apply the other approach that can enhance the students' oral communication in English speaking skill. One of the approaches is Communicative Language Teaching (CLT) or Communicative Approach. It is an approach for teaching the second and foreign language which emphasizes on the interaction as both the means and the ultimate goal of learning of a language. It is also referred to as "communicative approach to 
the teaching of foreign languages" or simply the "communicative approach". Effective communication is sought in CLT (Richard and Rodgers, 1986: 67).

The central theoretical concept in Communicative Language Teaching is "Communicative Competence," a term introduced into discussions of language use and second or foreign language learning in the early 1970s (Habermas 1970; Hymes 1971; Jakobovits 1970; Savignon 1971).

Nunan (1989: 10) defines communication activities as a piece of classroom work which involves learners in comprehending, manipulating, producing or interacting in the target language, while their attention is principally focused on meaning rather than form. In communicative activities, the students can use a variety of language rather than just one grammatical construction

In this research, the writer used the approach of Communicative Language Teaching (CLT) to motivate the students to communicate by using English orally. The teacher or lecturer is not the center in the teaching and learning process but he or she just gives the clues in order to push the students to speak. The students are encouraged to speak with the given topics. They can convey the ideas to develop their oral communication especially in speaking skill.

The strategies at this section on providing simple ways but powerful tools to improve oral communication in every classroom and all subject areas. Oral skill can help the teacher or lecturer to provide better feedback and guidance. The students need authentic opportunities to learn how to speak effectively in a variety of situations in pairs, in small and large groups.

Language teaching is not only teaching the patterns and then asking the students to memorize those patterns, but the important thing is that the students are able to understand and apply them in acceptable ways in the target language. Communicative Language Teaching (CLT), as an approach in language teaching focuses to enhance the oral communication especially in speaking skill among the learners.

\section{RESEARCH METHOD}

This research was conducted in two months. This research took place at Universitas Muhammadiyah Sorong. The samples of this research were two classes of students of English Education Department Faculty of Teacher Training and Education Universitas Muhammadiyah Sorong. This research applied Quantitative approach in order to obtain the comprehensive data. In this method, the research data could be in form of numbers and the analyzed is statistical. The information in this method dealing with numbers and that is measurable. Using quantitative research, it is possible to give precise and testable results. (Sugiyono 2009) 
This research was used to answer the two questions namely: (1). Can Communicative Language Teaching (CLT) enhances the student' oral communication and (2). How are the responses from the students in the learning process that applied through Communicative Language Teaching (CLT).

In order to answer the research problems, the writer used a design that shows the relationship between two variables, independent variable and dependent variable. This design called intactgroup comparison. This research will try to find out whether the result of a group which is given treatment is better than a group without treatment. A group which is given treatment is called as an experimental group and a group without treatment is called a control group. Arikunto. (1998). The research design could be seen in the table as follows:

The design of the research can be shown in this table.

\begin{tabular}{c|c|c}
\hline Group & Independent & Dependent \\
\hline Experimental & $\mathrm{X}$ & $\mathrm{Y} 1$ \\
\hline Control & - & $\mathrm{Y} 2$ \\
\hline
\end{tabular}

In Presenting the data, the writer used two kinds of instruments namely test and questionnaire. Test is series of questions or practical or other media are used for measure skill, knowledge, intelligence, ability or talent haves by individual or group. They are pre test and post test during the sixteen meetings. It was a tool to measure the effectiveness of Communicative Language Teaching (CLT) in speaking class. The test is based on the materials that had already given to the students. The test is the performance test.

Meanwhile, the questionnaire was used to obtain the data from students' responses about the use of the approach on communicative language teaching (CLT) in enhancing the students' oral communication. The questionnaire consisted of ten items.

\section{RESULT AND DISCUSSIONS}

After the data from the obtained score was collected, the writer classified the data into five categories.

Table 1. The category of the data was presented in the following table:

\begin{tabular}{c|c}
\hline Score & Classification \\
\hline A $(85-100)$ & Very High \\
B $(65-84)$ & High \\
C $(55-64)$ & Medium \\
D $(35-54)$ & Low \\
E $(0-34)$ & Very Low \\
\hline
\end{tabular}


The results of the data could be seen in the following table by applying the descriptive statistic of mean and frequency:

Table 2. The data of pre-test before treatment in experimental group

\begin{tabular}{c|c|c|c|c}
\hline \multirow{2}{*}{ Score } & \multicolumn{2}{|c|}{ Experimental Group } & \multirow{2}{*}{ Percentage } & \multirow{2}{*}{ Category } \\
\cline { 2 - 3 } & Frequency & Mean & & \\
\hline A $(85-100)$ & 20 & 54.13 & 62.50 & Very High \\
B $(65-84)$ & 10 & 23.16 & 31.24 & High \\
C $(55-64)$ & 1 & 1.88 & 3.13 & Medium \\
D $(35-54)$ & 1 & 1.72 & 3.13 & Very Low \\
E $(0-34)$ & - & - & - & Low \\
\hline & $\mathrm{N}=32$ & & 100 & \\
\hline
\end{tabular}

Based on the descriptive statistic table could describe of pre-test before treatment in experimental group above. The students who got A score were 20 students with mean score was $54.13(62.50 \%)$ in very high category. The students who got B score were 10 students with mean score was 23.16 (31.24\%) in high category. The students who got C score was 1 student, with mean score was $1.88(3.13 \%)$ in medium category, and there was 1 student got D score with mean score was $1.72(3.13)$ in low category.

Table 3. The data of pre-test without treatment in control group

\begin{tabular}{c|c|c|c|c}
\hline \multirow{2}{*}{ Score } & \multicolumn{2}{|c|}{ Control Group } & \multirow{2}{*}{ Percentage } & \multirow{2}{*}{ Category } \\
\cline { 2 - 3 } & Frequency & Mean & & \\
\hline A $(85-100)$ & 19 & 57.10 & 65.51 & Very High \\
B $(65-84)$ & 8 & 22.41 & 27.60 & High \\
C $(55-64)$ & - & - & - & Medium \\
D (35-54) & - & - & - & Very Low \\
E $(0-34)$ & 2 & 1.17 & 6.89 & Low \\
\hline & $\mathrm{N}=29$ & & 100 & \\
\hline
\end{tabular}

Based on the descriptive statistic table could describe of pre-test without treatment in control group above. For pre-test in control group, the frequency of the students who got A score were 19 students with mean score was $57.10(65.51 \%)$ in very high category. The frequency of the students who got B score were 8 students with mean score was $22.41(27.60 \%)$ in high category and the frequency of the students who got E score were 2 students with mean score was 6.89 (6.89\%) in very low category.

Table 4. The Resutls data of post-test after treatment in experimental group

\begin{tabular}{c|c|c|c|c}
\hline \multirow{2}{*}{ Score } & \multicolumn{2}{|c|}{ Experiment Group } & \multirow{2}{*}{ Percentage } & \multirow{2}{*}{ Category } \\
\cline { 2 - 3 } & Frequency & Mean & & \\
\hline A $(85-100)$ & 25 & 69.81 & 78.13 & Very High \\
B $(65-84)$ & 6 & 14.94 & 18.74 & High \\
C (55-64) & 1 & 2.00 & 3.13 & Medium \\
D (35-54) & & - & - & Very Low \\
E $(0-34)$ & - & - & - & Low \\
\hline & $\mathrm{N}=32$ & & 100 & \\
\hline
\end{tabular}


Whereas, based on the descriptive statistic table of post test could describe of post-test after treatment in experimental group above. The students who got A score were 25 students with mean score was $69.81(78.13 \%)$ and in very high category. The students who got B score were 6 students with mean score was 14.94 (18.74\%) and in high category, and there was 1 student got $\mathrm{C}$ score with mean score was $2.00(3.13 \%)$ in medium category. It meant that there was a significant effect when in the speaking class used Communicative Language Teaching (CLT) as a treatment.

Table 4. The Results data of post-test without treatment in control group

\begin{tabular}{c|c|c|c|c}
\hline \multirow{2}{*}{ Score } & \multicolumn{2}{|c|}{ Control Group } & \multirow{2}{*}{ Percentage } & \multirow{2}{*}{ Categor } \\
\cline { 2 - 3 } & Frequency & Mean & & \\
\hline A (85-100) & 20 & 61.90 & 68.97 & Very High \\
B (65-84) & 6 & 16.02 & 20.69 & High \\
C (55-64) & 2 & 3.79 & 6.89 & Medium \\
D (35-54) & 1 & 1.86 & 3.45 & Very Low \\
E $(0-34)$ & - & - & - & Low \\
\hline & $\mathrm{N}=29$ & & 100 & \\
\hline
\end{tabular}

Based on the descriptive statistic table of post test could describe of post-test in control group above. The frequency of the students who got A score were 20 students with mean score was 61.90 in very high category. The frequency of the students who got B score were 6 students with mean score was 16.02 in high category. The frequency of the students who got $\mathrm{C}$ score were 2 students with mean score was 3.79 in medium category and the frequency of the students who got D score was 1 student with mean score was $1.86(3.45 \%)$ in low category. It meant that the value of control group was lower than value of experimental group was higher.

In order to prove whether a Communicative Language Teaching (CLT) method had a significant effect in oral communication or speaking teaching and learning process, the writer used the formula of t-test related variants with the formula:

$$
\begin{aligned}
t_{o=} & \frac{\overline{X_{1}}-\overline{X_{2}}}{\sqrt{\left[\frac{\sum s 1^{2} \sum_{s 2} 2}{n 1+n 2}\right]-2 r\left[\frac{s 1}{\sqrt{n} 1}+\frac{s 2}{\sqrt{n 2}}\right]}} \\
& =86.75-81.69 \\
& =5.06 \\
& =2.70
\end{aligned}
$$

$t_{\text {table }}$ for DF (Degrees of Freedom) 30 was $2.021 \mathrm{t}$ observation was compared with $t$ table with the error

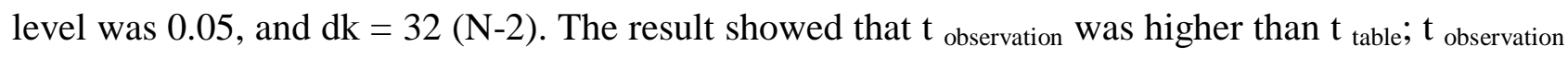
was 2.98 while $t$ table was $2.021(2.98>2.021)$. It means that there was a significant effect on the use of Communicative Language Teaching (CLT) method as a communicative approach towards the 
oral communication or speaking ability an English Education Department Faculty of Teacher Training and Education Universitas Muhammadiyah Sorong

Moreover, the results of the respondents' response about the Communicative Language Teaching (CLT) could be presented in the following table:

Table 6: The Results Data of the Respondents' Responses

\begin{tabular}{cc|c|c|c|c|c|c|c|c|c|c}
\hline \multirow{2}{*}{$\begin{array}{c}\text { Indi } \\
\text { cators }\end{array}$} & $\mathrm{N}$ & \multicolumn{9}{|c|}{ M e a } & \multicolumn{5}{c}{ Percentage } \\
\cline { 3 - 13 } & & 5 & 4 & 3 & 2 & 1 & 5 & 4 & 3 & 2 & 1 \\
\hline 1. & 32 & 2.8 & 1.5 & 0.2 & 0.0 & 0.0 & 56.3 & 37.5 & 6.2 & 0.0 & 0.0 \\
\hline 2. & 32 & 3.0 & 1.6 & 0.0 & 0.0 & 0.0 & 59.4 & 40.6 & 0.0 & 0.0 & 0.0 \\
\hline 3. & 32 & 1.4 & 2.5 & 0.3 & 0.0 & 0.0 & 28.1 & 62.5 & 9.4 & 0.0 & 0.0 \\
\hline 4. & 32 & 3.0 & 1.5 & 0.1 & 0.0 & 0.0 & 59.4 & 37.5 & 3.1 & 0.0 & 0.0 \\
\hline 5. & 32 & 2.5 & 1.9 & 0.1 & 0.0 & 0.0 & 50.0 & 46.9 & 3.1 & 0.0 & 0.0 \\
\hline 6. & 32 & 2.5 & 1.9 & 0.1 & 0.0 & 0.0 & 50.0 & 46.9 & 3.1 & 0.0 & 0.0 \\
\hline 7. & 32 & 1.3 & 2.5 & 0.3 & 0.1 & 0.0 & 25.0 & 62.5 & 9.4 & 3.1 & 0.0 \\
\hline 8. & 32 & 1.9 & 2.3 & 0.2 & 0.0 & 0.0 & 37.5 & 56.3 & 6.2 & 0.0 & 0.0 \\
\hline 9. & 32 & 1.6 & 2.8 & 0.0 & 0.0 & 0.0 & 31.2 & 68.8 & 0.0 & 0.0 & 0.0 \\
\hline 10. & 32 & 2.8 & 1.6 & 0.1 & 0.0 & 0.0 & 56.3 & 40.6 & 3.1 & 0.0 & 0.0 \\
\hline
\end{tabular}

a. The result data of indicator 1 (Communicative Language Teaching (CLT) is an aproach which is appropriate to be used in oral communication (speaking).

Most of the students tent to choose option 5 in this indicator. The mean score of option 5, for indicator 1 was 2.8. The percentage was 56.3. It could be said that the students were strongly agree on Communicative Language Teaching (CLT) approach it was suitable to teach oral communication or speaking.

b. The result data of indicator 2 (Communicative Language Teaching (CLT) improves the motivation of the student to learn).

In the second indicator, most of the students chose option 5. The mean score of option 5, for indicator 2 was 3.0. The percentage was 59.4. It could be said that the students were strongly agree on Communicative Language Teaching (CLT) approach that can improve the motivation of the students to learn, especially in speaking or oral communication.

c. The result data of indicator 3 (the forms of Communicative Language Teaching (CLT) activities are interesting for the students).

For the third indicator, the students tent to choose option 4 . The mean score for option 4 , of indicator 3 was 2.5. The percentage was 62.5. It could be said that the students were agree if Communicative Language Teaching (CLT) approach have many forms of activities to teach oral communication or speaking and it made the students were interesting in the learning process. 
d. The result data of indicator 4 (the students are to be active in the class by using Communicative Language Teaching (CLT)).

The mean score for option 5 of indicator 4 was 3.0. The percentage was 59.4. It could be said that the students were strongly agree on the indicator of Communicative Language Teaching (CLT) approach made the students to be active to interact in the class when learning process.

e. The result data of indicator 5 (Communicative Language Teaching (CLT) enhances oral communication or speaking of the students).

The mean score for option 5 of indicator 5 was 2.5. The percentage was 50.0. It meant that the students were strongly agree on Communicative Language Teaching (CLT) approach which can enhance oral communication or speaking among the students.

f. The result data of indicator 6 (Communicative Language Teaching (CLT) makes the students confidence to make interaction (speaking) with another students).

The mean score for option 5 of indicator 7 was 2.5. The percentage was 50.0. It could be said that the students were strongly agree on the indicator of Communicative Language Teaching (CLT) approach made the students have confidence on oral communication or speaking with another students in speaking class.

g. The result data of indicator 7(in Communicative Language Teaching (CLT) activities, the students are be brave to speak communicatively, regardless their grammar).

The students tent to choose option 4 . The mean score for option 4 of indicator 7 was 2.5. The percentage was 62.5 . It could be said that the students were agree on the indicator of Communicative Language Teaching (CLT) activities made the students are be brave to speak communicatively with another students regardless their grammar.

h. The result data of indicator 8 (communicative activities provide opportunities for developing personal relationship between learners and lecturer).

The mean score for option 4 of indicator 8 was 2.3. The percentage was 56.3. We could say that the students were agree on this indicator of Communicative Language Teaching (CLT) activities provided positive personal relationship between the students and lecturer. The student felt a close relationship with the lecturer, therefore, in the class, the students were be brave to interact with their lecturer.

i. The result data of indicator 9 (Communicative Language Teaching (CLT) creates natural situation, in the process of learning in the classroom). 
The mean score for option 4 of indicator 9 was 2.8 . The percentage was 68.8. It means that the students agreed on Communicative Language Teaching (CLT) activities created natural situation in the process of learning in the classroom and the learning process want happened fluently without the feeling of depression among the students because they usual thought that english subject, especially speaking was not very difficult.

j. The result data of indicator 10 (Communicative Language Teaching (CLT) makes the students interest in speaking in and out of the classroom).

The mean score for option 5 of indicator 10 was 2.8 . The percentage was 56.3 . It could be said that the students were strongly agree on the application of Communicative Language Teaching (CLT) approach which made the students interested in speaking for interacting with another students in and out of the classroom.

From findings, the researcher can explaine some points.

1. The Students' oral communication or speaking ability.

Referring to score of the students' speaking ability through Communicative Language Teaching (CLT) in the experimental group and control group, it could be said that in the experimental group, the mean score of the test before and after treatments was different. Before treatment in pre-test, the mean score of the students was 54.13 (very high category), 23.16 (high category), 1.88 (medium category), 1.72 (low category) and none of the students got very low category. There were 20 students $(62.50 \%)$ were in very high category, 10 students $(31.24 \%)$ were in high category, 1 student $(3.13 \%)$ were in medium categories, 1 student $(3.13 \%)$ were in very low category and none student got very low category. After treatments in the post-test, the mean score was 69.81 (very high category), 14.94 (high category), and 2.00 (medium category).

However, classification became very high, high, medium, and none of them got low and very low anymore. The students were classified in which there were 25 students $(78.13 \%)$ got very high scores, 6 students (18.74\%) got high scores, 1 student (3.13\%) got medium score, and none of the students was classified low and very low scores. It means that the students' scores in this group increased from a low score to very high score.

In the control group, it was revealed by the mean score of the students without treatments. Where in the pre-test, the mean score from the speaking 3 which was taken from the last semester was 57.10 (very high category), 22.41 (high category), 1.77 (very low category), and none students got medium and very low category. There were 19 students $(65.51 \%)$ were in very high category, 8 students $(27.60 \%)$ were in high category, 2 students $(6.89 \%)$ were in very 
low categories, and none students got medium and low category in percentage. Where in the post-test the mean score from the speaking 4 of students was 61.90 (very high category), 16.02 (high category), 3.79 (medium category), and 1.86 (low category) and none students got very low category. The level of classification became very high, high, medium, low and none of them very low. The students were classified in which there were 20 students $(68.97 \%)$ students very high scores, 6 students $(20.69 \%)$ got high scores, 2 students $(6.89 \%)$ got medium score, 1 student $(3.45 \%)$ got low score, and none students was classified very low scores. It means that the students' scores in this group increased.

The data in the previous section showed that the use of the Communicative Language Teaching (CLT) gave a better effect in learning and teaching speaking in the experimental group than in control group. It also can be seen from the mean scores of both the control and the experimental group in the post-test is expressively different (see Table 4 and 5).

The experimental group used Communicative Language Teaching (CLT) approach with debate activities and the control group without treatment made a difference. One of the differences of Communicative Language Teaching (CLT) made the students felt better and interest in speaking class. This approach was able to build the students' speaking ability be better than before. So, it can be inferred statistically based on t-Test value that Communicative Language Teaching (CLT) was more effective in increasing the students' speaking ability (see page 53).

2. The Students' responses towards the application of Communicative Language Teaching (CLT) as an approach

The description of the data collected through the students' responses in speaking using Communicative Language Teaching (CLT) as explained in the previous part shows that the students' responses of the questionnaire is positive. Some students gave responses strongly agree and some of them are agree with the application of Communicative Language Teaching (CLT) as an approach and it is used in learning process (see table 5).

\section{CONCLUSIONS}

Communicative Language Teaching (CLT) as an approach in language teaching, focuses to enhance the oral communication especially in speaking skill among the learners. It is shown that based on the results data in experimental group, in which Communicative Language Teaching (CLT) is use as treatment, the mean of very high score was 69.81 and the mean of high score was 
14.94. There was 25 students who could achieve very high score (78.13\%) and 6 students who could achieve high score $(18.74 \%)$. Whereas, in control group, the mean of very high score was 61.90 and the mean of high score was 16.02. There were 20 students who got very high score $(68.97 \%)$ and 6 students who got high score (20.69\%). It can be proved that there was a significant effect on the use of Communicative Language Teaching (CLT) in teaching oral communication or speaking to the students. It showed that $\mathrm{t}$ observation was 2.98 while $\mathrm{t}$ table was $2.021(2.98>2.021), \mathrm{t}$ observation was bigger than $\mathrm{t}$ table.

The students said that they were strongly agree when Communicative Language Teaching (CLT) was applied in speaking learning process because it would help them to improve their ability in oral communication or speaking. It showed that from table 6 (the results dat of the respondent's responses. The results data of indicator 1 and indicator 10 the students tent to choose option 5 (strongly agree). They have same percentage was $56.3 \%$ with mean score was 2.8 . The results data of indicator 2 and indicator 4 showed that the students tent to choose option 5 (strongly agree). Both of them have same percentage, it was $59.4 \%$ with the mean score of 3.0. The results data of indicator 3 and indicator 7 showed that the students tent to choose option 4 (agree). Both of them have same percentage, it was $62.5 \%$ with the mean score of 2.5 . The results data of indicator 5 and indicator 6 , it showed that the students tent to choose option 5 (strongly agree). Both of them have same percentage, it was $50.0 \%$ with the mean score of 2.5 . The results data of indicator 8 and indicator 9 showed that the students tent to choose option 5 (strongly agree). But they have different percentage and mean score, in indicator 8 the percentage, it was $56.3 \%$ with mean score of 2.3 , whereas in indicator 9 the percentage was $68.8 \%$ with mean score of 2.8 .

\section{REFERENCES}

Akib, R. (2018). First Language Interference in English Speaking Performance of University Students of Muhammadiyah Sorong (UMS). Qalam: Jurnal Ilmu Kependidikan, 6(1), 22-32.

Amaliyah, R., Akib, M., \& Hartanti, R. (2018). The Use Of Group Investigation Method To Improve Students' Speaking Ability At English Department Of Sorong Muhammadiyah University. Qalam: Jurnal Ilmu Kependidikan, 6(2), 24-31.

Arikunto, Suharsimi. (1998). Prosedur Penelitian: Suatu Pendekatan Praktek. Edisi: Revisi IV. Jakarta: Rineke Cipta.

Clark, H.H, and Clark, Ave V. (1977). Psychology and Language: An Introduction to Psycholinguistics. New York: Harcourt Brace Jovanovich, Inc.

Harmer, J. (1994). The Practice of English Language Teaching. Cambridge: Cambridge: University Press 
Hornby, A. S. (1984). Oxford Advanced Learner's Dictionary of Current English. Oxford University Press.

Laddo, R. (1961). Language Teaching: Teaching Contribution and Use of Foreign Language Test. London: Longman Group Lomitid.

Illeris, 2000; Ormorod,( 1995). Developing Communicative Proficiency in the English as a Foreign Language Class. Jakarta: Depdikbud P2LPTK.

Nunan, D. (1989). Designing Tasks for the Communicative Classroom. Cambridge: Cambridge: University.

Ridchard, J.C and Rodgers, T.S (1986). Approaches and Methods in Language Teaching. Cambridge: Cambridge University Press.

Saputra, D. (2018). Developing Students' Vocabulary Mastery through Video Game. Qalam: Jurnal Ilmu Kependidikan, 6(1), 47-54.

Sugiyono. (2009). Metode Penelitian Kuantitatif dan $R \&$ D. Bandung: Alfabeta. 